\title{
ОСОБЛИВОСТІ КОМПОЗИЦІї РЕЦЕНЗІї НА ТЕРМІНОЛОГІЧНИЙ СЛОВНИК
}

У статті визначено особливості композиції рецензії на термінологічний словник: (1) різнорівневість і полікомпонентність ї̈ системної організації, (2) залежність змісту композиційних компонентів від суті положень алгоритму поетапного оцінювання термінологічних словників, (3) аналітичність компонентів рецензіі (значна кількість відповідних ім субкомпонентів). З'ясовано, що рецензія на термінологічний словник є ієрархічною гранд- / мегаструктурою; складники рецензіі - Заголовок, Вступ, Основна частина й Висновки - $є$ співкомпонентами нижчого рівня ієрархї, що створюють ї макроструктуру; субкомпоненти формують ї мікроструктуру.

Ключові слова: рецензія на термінологічний словник, композиція, компоненти композиції, субкомпоненти, гранд- / мегаструктура, макроструктура, мікроструктура, термінологічний словник.

Petrova T. Composition Features of Terminology Dictionary Review. Studying the composition features of a review is a necessary basis for the analysis of a scientific text, since understanding the general principle of the work composition will facilitate to explain the functions of each component.

The purpose of the article is to determine the composition features of a terminology dictionary review and to develop its invariant model; the task is to select the composite components of a special dictionary review and to characterize their features. Structural, descriptive and comparative methods as well as the method of lexicographic and quantitative analysis were applied in the research.

The composition of a terminology dictionary review is not only the form or the way of scientific information organization but also the way to summarize the results of evaluating the multilevel parameters of a primary work - a professional dictionary.

An invariant model of the composition of a terminology dictionary review is a multilevel structure, in particular: the composition of a terminology dictionary review $\rightarrow$ the components of its composition (title, introduction, main part and conclusions) $\rightarrow$ the subcomponents of its specific component. The composition of a terminology dictionary review is a hierarchical grand / megastructure; the constituents (components) of the review, namely: Title, Introduction, Main Part and Conclusions are the co-components of the lower hierarchy level and create its macrostructure; the subcomponents form its microstructure.

The composition features of a special edition review are (1) the multilevel and polycomponental structure of its system organization, (2) the dependence of the composite components content on the essence of the algorithm of the terminology 
dictionary gradual evaluation, (3) the analyticity of the review components, i.e. a significant number of the relevant subcomponents. The proposed invariant scheme-model of the composition of a terminology dictionary review as a multilevel system is a navigator during the complex process of reviewing the terminographic work.

This scheme-model has a methodological basis, namely - focusing on a step-bystep algorithm for lexicographic examination of special editions - and will facilitate a comprehensive, reasoned and objective analysis, avoidance of subjectivism and violation of the features and boundaries of a review as a genre variety of the critical sub-discourse. The review created on the invariant scheme-model proposed will facilitate to develop a stable pragmatic genre form and testify to the qualitative changes in the terminographic criticism and compiling professional dictionaries.

Key words: terminology dictionary review, model of review composition, composition components, subcomponents, grand / megastructure, macrostructure, microstructure, terminology dictionary.

\section{Вступ}

Вивчення особливостей композиції - необхідне підгрунтя аналізу наукового тексту, оскільки, «лише усвідомивши загальний принцип побудови твору, можна правильно пояснити функції кожного елемента чи компонента тексту. Без цього неможливе правильне розуміння ідеї, смислу всього твору або його частин» (перекл. автор. - Т. П.) (Кайда, 2006: 36). Звісно, «основна мета наукового стилю - повідомлення об'єктивної інформації, доведення істинності наукового знання» (Космеда, 2017: 226), що здійснюється через реалізацію продуманої структури кожного виду наукового жанру. Власне й композиція рецензії на спеціальний словник потребує ретельного розгляду та систематизування, оскільки рецензія як різновид критичного, виразно оцінювального наукового жанру має важливе теоретико-практичне значення.

На сьогодні специфіку структурної організації рецензії активно вивчають такі дослідники: українські - О. Гуманенко (рецензії на наукові твори /Гуманенко, 2015/), Ж. Краснобаєва-Чорна (україномовні мовознавчі рецензії /Краснобаєва-Чорна, 2010/), I. Левчук (українські та польські мовознавчі рецензії/Левчук, 2003, 2004, 2013/), Г. Онуфрієнко (рецензії на наукові джерела /Онуфрієнко, 2009/), О. Добровольський, М. Хойнацький та М. Тимошик (експертна рецензія /Добровольський \& Хойнацький, 1991; Тимошик, 2006/), О. Тищенко (грецькі газетні літературні рецензії /Тищенко, 2017/), С. Яворська (англомовні науково-теоретичні, науково-популярні, 
художньо-публіцистичні рецензії /Яворська, 2000/), Н. Яценко (наукова рецензія /Яценко, 2017/) та ін.; литовські - А. Бєловодська (рецензії медіадискурсу /Беловодская, 2016/), Е. Лассан (літературна рецензія / Лассан, 2012/) та ін.; російські - О. Зінова (журналістська рецензія /Зинова, 2012/), М. Карнаухова (літературна рецензія /Карнаухова, 2010/) та ін. Попри широке вивчення українськими та зарубіжними науковцями специфіки структури різних типів рецензій, особливостям побудови рецензій на термінологічні словники досі не приділено належної уваги, що й визначає актуальність цієї наукової розвідки.

Мета статті - висвітлити особливості композиції рецензії на термінологічний словник; завдання - виділити композиційні складники рецензії на спеціальний словник та розробити іï інваріантну модель.

\section{Методи та методики дослідження}

У статті застосовано структурний метод (для вивчення тексту рецензії як цілісної системи), описовий (для систематизування компонентів композиції рецензії на фаховий словник), порівняльний (для зіставлення змісту частин побудови рецензій), метод кількісного аналізу (для визначення співвідношення кількісного вияву композиційних компонентів рецензії та їхного використання), метод лексикографічного аналізу (для визначення й характеристики лексикографічних параметрів словника).

\section{Результати та дискусії}

У науковій літературі на позначення будови рецензії використовують такі терміни: структурно-семантична організація рецензї (Левчук, 2003), семантико-композиційна структура / організація рецензї (Яценко, 2017), композиційна структура рецензї (Тищенко, 2017), структурно-композииійне жанрове утворення (Молитвина, 2016) тощо. Неусталеність термінології критичного субдискурсу засвідчує факт проходження етапу становлення термінографічної критики як науки, а також нагальну необхідність вивчення композиційних особливостей наукової рецензії, зокрема на спеціальні словники. «Літературний енциклопедичний словник» пояснює поняття «композиція» так: «розташування і співвіднесеність компонентів худож. форми, тобто побудова твору, зумовлена його змістом і жанром. <..> К. скріплює елементи форми й підпорядковує їх ідеї» (Литературный энциклопедический словарь, 1987: 164), 
а «структура» - це «особлива організація, взаємозв’язок елементів літ. тексту, при якому змінення одного з них спричиняє змінення інших» (Литературный энциклопедический словарь, 1987: 426). Визначення понять, як бачимо, збігаються, тобто є синонімними, про що в названому словнику зазначено: «Як синоніми терміна «К.» нерідко використовуються терміни «архітектоніка» й «структура»; однак поширені й інші, специфічні визначення цих термінів» (Литературный энциклопедический словарь, 1987: 164).

«Словник сучасної лінгвістики: поняття і терміни» теж репрезентує зміст аналізованих понять як синонімних, порівн.: «Структу́ра $<\ldots>-1)$ те саме, що будова мовної одиниці <...>. Структу́ра сло́ва. Структу́ра ре́чення. Структу́ра словосполу́чення, Структу́ра те́ксту; 2) сукупність відношень і зв'язків між елементами (одиницями) мовної системи, $\langle\ldots\rangle$, та сукупність відношень між елементами (одиницями) у лінеарних послідовностях <...» (Загнітко, 2012: Т.3: 385-386); «Компози́ція <..> - структура, побудова твору певного жанру, художній план твору, де співвідношення частин зумовлене темою і задумом; структура, що передбачає використання відношень єдності «первинних» елементів за законом композиції (Загнітко, 2012:T.2: 64). Отже, на позначення організації чи єдності інформації або частин у науковому тексті існують як абсолютні синоніми чужомовні спеціальні найменування композиція й структура, а також питома назва побудова. Однак, на наше переконання, доречно послідовно застосовувати номінативні одиниці для найменування частин побудови наукового тексту як єдності, зокрема: обравши термін композиція наукового тексту, доцільно вживати одиницю компоненти композиції наукового тексту; структура наукового тексту - елементи структури наукового тексту. У цьому дослідженні оперуємо терміноодиницями композиція рецензії на спеціальний словник й компоненти наукової рецензї̈ на спеціальний словник.

Композиція рецензії на термінологічний словник - це не лише форма чи порядок організації наукової інформації, а й спосіб узагальнення результатів оцінювання різнорівневих параметрів первинної праці - словника. Роль композиції полягає в тому, що завдяки ій «текст не розпадається на механічну купу окремих, незалежних шматків, а щільно цементується в одне смислове ціле. Композиція струнко зв'язує й узгоджує все, про що пише автор» (Селігей, 2015: 
54). Недотримання композиції тексту такого типу загрожує стиранням ознак рецензії на словник як жанру, а відповідно, її вимиранням.

Показниками вдалої композицї наукового тексту є зв'язність, цільність, співмірність і врівноваженість частин тексту, ритмічність ї зміни, ієрархічність (другорядне підпорядкування головному), завершеність (результат відповідає задуму) (Селігей, 2015: 54). Композиційними вадами наукового тексту називають затягнутий вступ, брак чітких висновків, одноманітність композиційно-стильових прийомів, невміння змінювати будову тексту, порушення пропорцій між абстрактним і конкретним, між позитивним і негативним матеріалом, між емоційним і раціональним (Михневич, 1984: 167).

Рецензія за обсягом «є малим жанром, за ступенем узагальнення - вторинним, а за критерієм свободи й розгортання змістовносмислової специфіки повідомлення й також вибору мовних засобів, - текстом, що грунтується на узусних інформативних моделях, композиційно-смисловою організацією - «відкритою», «вільною» та «м'якою» структурою» (Петрова, 2019а: 135). Кожен рецензент термінологічного словника може виробити свій підхід до побудови рецензіi, однак вона повинна відповідати певним правилам / вимогам, бути аргументованою та кваліфікованою. На основі вивчення англомовної рецензії науково-теоретичного характеру функціонального стилю наукової прози С. Яворська підкреслює: «Вимоги до оформлення текстів наукових рецензій жорсткі, спрямовані на досягнення ними лаконізму викладу, точності, недвозначності, відсутності емоційнозабарвлених суб’єктивних рекомендацій автора» (Яворська, 2000: 7). За авторськими спостереженнями, композиція українських наукових текстів передбачає дотримання правил ії побудови, але якщо стосовно написання тексту дисертацій, авторефератів, монографій, а також наукових статей висувають суворі вимоги, то до створення рецензій на термінологічні словники не формулюють жодних правил. Основною вимогою до побудови рецензії, як видається, $є$ композиційна єдність їі частин.

Ураховуючи текстоцентричний підхід до вивчення наукової комунікації, лінгвісти виділяють рецензію в окремий текстотип, «семантикокомпозиційна, комунікативно-прагматична та лексико-синтаксична організації якого підпорядковані потребі представити зміст рецензованого тексту, інтерпретувати та оцінити його» (Яценко, 2017: 93). 
Зауважмо, що загалом усі наукові тексти поділяють на дві групи: 1) тексти, побудовані за моделями чіткого, жорсткого типу; 2) тексти, створені за моделями гнучкого, вільного типу (Яворська, 200: 10). У науковій літературі існує думка, що «композиція тексту - явище варіативне, жорстка ії стандартизація навряд чи доцільна. По-перше, немає жодного композиційного правила, порушуючи яке, не можна було 6 написати хорошого наукового твору. По-друге, розвиток літературної мови - це невпинне порушення вироблених у минулому правил (інакше не було 6 самого розвитку). По-третє, надто сувора схема викладу неминуче схематизує й саму думку» (Селігей, 2015: 59). Дозволимо собі не погодитися із цим, оскільки, очевидно, і можна написати якісний науковий текст без застосування правил чи вимог до нього, але не рецензію на термінографічну працю. Рецензії на термінологічні словники «мають важливе теоретико-практичне значення: систематизування виявлених критичних оцінок і недоліків репрезентування структурних параметрів видань такого типу сприятиме вдосконаленню теоретико-методологічних основ метатермінографії задля практичного якісного реалізування спеціальних праць» (Петрова, 2019 б: 103). Необхідно орієнтуватися не лише на особливості композиції рецензії, а й ураховувати, що рецензія на спеціальну працю є базовим жанром термінографічної критики, «вторинним текстом, у якому виклад інформації грунтується на результатах оброблення та аналізування первинного тексту термінографічного видання. Композиційні елементи рецензії підпорядковані конкретній меті: комплексно, усебічно оцінити й схарактеризувати рецензований термінологічний словник» (Петрова, 2018: 211). Отже, рецензія на спеціальний словник - це вторинний жанр наукового стилю, стаття критичного характеру, що має композицію 3 «подвійним дном», яка залежить від структурних особливостей первинного тексту, тобто специфіки побудови термінологічного словника.

Науковці по-різному підходять до виділення складників рецензії та їхньої кількості. Найбільш поширена думка щодо організації рецензії базується на необхідності врахування чотирьох ії складників. Утім Н. Яценко наголошує, що: «традиційно рецензія вирізняється п’ятикомпонентною архітектонікою і передбачає єдність заголовка, вступу, основної частини та висновку» (Яценко, 2017: 99). Ця дослідниця називає складники наукової рецензії - заголовок, вступ, основну 
частину, висновок - композиційними елементами (темами). До того ж вона виділяє чотири елементи, а заявляє про «п'ятикомпонентну архітектоніку рецензіі» (Яценко, 2017: 99).

I. Левчук у композиційній організації мовознавчої рецензії виділяє заголовок, бібліограбічний опис, вступ, основну частину, висновки (Левчук, 2004), тобто п’ять компонентів. Зазначена науковиця вважає, що «кожний композиційний елемент є закономірним етапом в оцінній характеристиці рецензованої публікації, має певну прагматичну настанову й відповідне змістове та графічне оформлення в тексті» (Левчук, 2013: 101).

О. Добровольський, М. Хойнацький та М. Тимошик визначають у композиції експертної рецензії три иастини: загальну, докладного аналізу оригіналу (посторінкового розгляду), висновок (Добровольський \& Хойнацький, 1991: 65; Тимошик, 2006: 228). Ж. Краснобаєва-Чорна виділяє три основні структурні типи оцінного дискурсу - мовознавчої рецензії: перший - 1. Встуn - оцінка '+ / -' / нейтральна (анотований вступ), обов'язковий компонент. 2. Основна частина - оцінка '+ / -', обов'язковий компонент. 3. Висновок - оцінка '+ / -', обов'язковий компонент. 4. Література - факультативний компонент; другий - 1. Епіграф / Анотація, факультативний компонент. 2. Встуn - оцінка '+ / -' / нейтральна, обов'язковий компонент. 3. Основна частина складається з двох окремих блоків: оцінка '+', оцінка '-', обов'язковий компонент. 4. Висновок - оцінка '+', обов'язковий компонент; третій - 1. Встуn - оцінка '+ ', обов' язковий компонент. 2. Основна частина - оцінка '+', обов'язковий компонент. 3. Висновок - оцінка '+', обов'язковий компонент (Краснобаєва-Чорна, 2010: 217). Єдиного погляду щодо виділення компонентів рецензії і їхньої кількості, як бачимо, не існує.

У процесі вирізнення складників відповідних компонентів рецензії також відстежуємо відсутність одностайності в судженнях дослідників. Наприклад, Н. Молитвина основну частину літературної рецензії розбиває на тематичні фрагменти (Молитвина, 2016: 233); Н. Яценко в межах композиційних елементів (тем) наукової рецензії виокремлює мікротеми, які поділяє на змістові блоки. Зокрема, у Bcmyni вона виділяє мікротеми «констатація факту появи праці», «ступінь вивчення проблеми», «автор праці»; в Основній частині прац̧і - мікротеми «здобутки праці» (актуальність, новизна, корисність 
і практична цінність, мова і стиль праці тощо), «вади праці», «адресат»; окремо подає Висновок (Яценко, 2017: 93); водночас зауважмо, що назву останнього компонента доречно подавати у формі множини (Висновки), оскільки в кінцевому підсумку аналізу зазвичай викладають не один, а всі його результати. Також наголосімо на тому, що деякі мовознавці в одній статті одночасно можуть використовувати терміни-варіанти міні-тема рецензії й мікротема рецензї на позначення певного складника компонента мовознавчої рецензії (Левчук, 2003).

Функціювання варіантів найменування ключових понять термінографічної критики засвідчує незакінчене формування ії метамови, а також відсутність єдиних погляду й підходу стосовно членування композиції рецензії. У цій роботі для характеристики змістового наповнення кожного компонента рецензії використовуємо поняття «субкомпонент» на позначення тематичного складника компонента композиційної системи рецензії на термінологічний словник.

Набір жанроутворювальних ознак рецензії впливає на вибір компонентів ії композиції, зміст, стиль. Гіпотетично рецензія на термінологічний словник як базовий жанр термінографічної критики повинна передбачати певну інваріантну модель (зразок) композиції, iï модифікації відтворюються в жанрових різновидах - варіантах побудови критичної публікації. «Вибір форми й структурних компонентів тексту рецензії на термінологічні словники та їхнє конкретне мовне наповнення залежать від вираження авторського “я” (Ego), тобто від вияву ставлення автора до відтворюваних ним фактів, фаху (термінограф / галузевий фахівець) і мети (оцінної / інформативної) експерта. Зокрема, в одних рецензіях основною метою критика може бути оцінювання позитивних моментів і зазначення недоліків, а в інших - висвітлення ролі й місця словника в певній науці чи галузі знання, термінологію якої в ньому описано» (Петрова, 2019а: 137).

Проаналізувавши англомовні тексти науково-теоретичної, науково-популярної, рекламної рецензії, експрес-рецензії, стислої літературно-художньої та мистецької рецензії, звичайної газетної / журнальної рецензії та рецензії-есе, С. Яворська запропонувала інваріантну модель тексту рецензї: «і (інформація про видання) - д (iсторична довідка про час або обставини написання твору) - 3 (зміст твору) - о (переконлива оцінка автора), або і-д-3-о» (Яворська, 2000: 16). А. Бєловодська в складі інваріанта рецензії розглядає блоки: 
інформативний блок, оиінювальний блок, аналітичний блок (аргументаційно-аналітичний) (Беловодская, 2016: 36).

Т. Хомутова й Е. Кравцова на основі базової інтегральної моделі наукового тексту розробили інтегральну модель наукової рецензї, де виділяють чотири сектори, у кожному наукову рецензію розглядають з урахуванням різних аспектів: когнітивного - ураховує «фрагмент спеціального наукового знання певної галузі» (Хомутова \& Кравцов, 2014: 73); соціального - спроєктований на «фрагмент соціального простору у вигляді соціального контексту акту спеціальної наукової комунікації - дискурсу» (Хомутова \& Кравцов, 2014: 73); культурного - «фрагмент культури, що грунтується на культурних цінностях того чи того народу» (Хомутова \& Кравцов, 2014: 75); мовного - «фрагмент мови як предмета (мовної системи й мовного матеріалу), а саме фрагмент спеціальної підмови, у якому за допомогою мовних засобів (лексики, оцінювальної лексики та граматики тексту) виражаються декларативне й процедурне знання, культурні цінності, соціальні концепти та події» (переклад автор. - Т. П.) (Хомутова \& Кравцов, 2014: 75). Зазначені науковці простежують тісний взаємозв'язок усіх чотирьох секторів наукової рецензії, через який можна виявити глибинні механізми, що лежать в основі наукової комунікації. Співвідносячи інваріант рецензії з ії композицією, мовознавці без застережень виокремлюють у ній заголовок, вступ, основну частину й висновки.

$€$ сенс, як видається, спиратися й на вироблені українськими (Онуфрієнко, 2009: 254) та зарубіжними (Карнаухова, 2010: 89) науковцями алгоритми підготовки рецензій. Наприклад, Г. Онуфрієнко запропонувала алгоритмічний припис до рецензування наукового джерела: «1. Визначте предмет наукового аналізу (доповідь, реферат, журнальна стаття, твір-есе, автореферат, дисертація тощо). 2. 3’ясуйте ступінь актуальності теми дослідження (для науки в цілому, певної галузі знань, розв'язання практичних завдань тощо). 3. Проаналізуйте зміст наукової роботи і з'ясуйте ступінь ії новизни й оригінальності у розв'язанні певних питань, проблем тощо. 4. Встановіть достоїнства рецензованої роботи в контексті іï теоретичного й практичного значення та зазначте конкретні сфери доцільного використання матеріалів і результатів iii. 5. Схарактеризуйте виявлені недоліки та прорахунки в рецензованій роботі за обов'язкової умови - аргументувати свої зауваження. 6. Подайте об’єктивно, лаконічно, ясно й чітко загальну оцінку роботи. 
7. Сформулюйте висновки з урахуванням виду та жанру рецензованого наукового джерела, його мети й поставлених автором завдань. 8. Перевірте записаний текст рецензії на узгодженість між змістом і формою та на відповідність чинним мовним / мовленнєвим нормам. 9. Здійсніть самоконтроль виконаної роботи. 10. Відредагуйте (у разі потреби) текст рецензї» (Онуфрієнко, 2009: 254).

Спираючись на напрацьовані підходи до організації композиції наукової рецензії, вироблені інтегральну та інваріантну моделі наукової рецензіі, алгоритми написання рецензій, а також власні результати аналізу текстів рецензій, пропонуємо інваріантну модель різнорівневої композиції рецензії на термінологічний словник: «композиція рецензії на термінологічний словник $\rightarrow$ компоненти ії композиції (заголовок, вступ, основна частина, висновки) $\rightarrow$ субкомпоненти ї певного компонента». Визначмо істотні змістові характеристики компонентів рецензії та їхніх субкомпонентів.

1. Компонент Заголовок рецензії на спеціальний словник виконує, крім номінативної, й інші функції, насамперед комунікативну, гносеологічну, мислетворчу, креативну i, головне, функцію поширення наукових знань. Зазвичай заголовок - це бібліографічний опис словника (може бути повним або коротким). Науковці припускають, що "рецензія виникла саме з бібліографічного опису книги, який із часом почав давати також її оцінку» (Левчук 2013: 99). Бібліографічний опис опосередковано, через указівку на відомі видавництва чи авторитетних рецензентів, які є гарантами кваліфікованої роботи, може «повідомляти наперед, анонсувати» про очікувану високу якість словника.

Прийнято вважати, що заголовок «не містить безпосередньої оцінки публікації, а отже, не є власне оцінним етапом» (Левчук, 2013: 101). Дозволимо собі не погодитися із цим твердженням, оскільки сучасні заголовки можуть не повторювати назви рецензованого словника (вона може бути у вступі) й віддзеркалювати ставлення автора, містити прозору оцінку, а також виконувати експресивну функцію, що невластива заголовкам наукових текстів (напр., рец. І. Кочан До вершин економічної термінології на Фінансово-економічний словник, 2012; П. Ляшкевича Театр починається зі словника на Словник теampy, 2007). «Заголовок, будучи одним з найбільш значущих елементів тексту, $є$ початковим імпульсом для сприйняття тексту рецензії 
читачем» (Зинова, 2012). Фактично компонент Заголовок першим дає інформацію про словник, він налаштовує читача на сприйняття оцінки видання, тому має неабияке значення, яке слід ураховувати під час продумування композиції рецензії на словник.

Наступні компоненти досліджуваної композиції рецензії- Вступ, Основна частина, Висновки - повинні підпорядковуватися алгоритму аналізу термінологічних словників, суть якого полягає в поетапному оцінюванні мега-, макро- й мікроструктури термінографічного видання стосовно відповідності чи невідповідності критеріям (табл.). Цей алгоритм $є$ своєрідною схемою порівневого й покрокового експертизування фахового видання. Авторка цього дослідження переконана, що дотримання критиками викладеного нижче алгоритму й застосування критеріїв рецензування термінографічних праць забезпечить повний аналіз словників, стане запорукою вироблення єдиного принципу критичного оцінювання видань такого типу й сприятиме підвищенню якості словникової продукції (Петрова, 2018: 212).

Алгоритм поетапного оцінювання термінологічних словників

Таблиця

\begin{tabular}{|c|c|}
\hline Етапи & Зміст роботи \\
\hline $\begin{array}{c}\text { Перший } \\
\text { етап }\end{array}$ & $\begin{array}{l}\text { 1. Аналіз мегаструктурних частин (вступу або передмови, правил } \\
\text { користування, переліку скорочень, корпусу словника, списку джерел, } \\
\text { покажчика) словника на відповідність принципам їхньої побудови. } \\
\text { 2. Установлення відповідності типу словника, заявленого в тексті перед- } \\
\text { мови, реальному. } \\
\text { 3. З’ясування відповідності призначення словника, зафіксованому в пе- } \\
\text { редмові. } \\
\text { 4. Визначення наукової цінності словника і його відповідності запитам } \\
\text { користувачів. }\end{array}$ \\
\hline $\begin{array}{c}\text { Другий } \\
\text { етап }\end{array}$ & $\begin{array}{l}\text { 1. Критика макроструктури (реєстру термінів) словника стосовно від- } \\
\text { повідності способу іï побудови. } \\
\text { 2. Аналіз термінологічного складу словника. } \\
\text { 3. Експертизування реєстрових терміноодиниць щодо відповідності вимогам } \\
\text { до термінів. }\end{array}$ \\
\hline $\begin{array}{c}\text { Третій } \\
\text { етап }\end{array}$ & $\begin{array}{l}\text { 1. Аналіз мікроструктури (термінологічної статті) словника за крите- } \\
\text { рієм ефективності репрезентування інформації. } \\
\text { 2. Оцінювання мікроструктурних параметрів (заголовного терміна, } \\
\text { варіантів, акцентної характеристики, граматичної характеристики, ети- } \\
\text { мологічної довідки, дефініції, системних відношень) словника за крите- } \\
\text { рієм якості їхнього подання (Петрова, 2018: 212). }\end{array}$ \\
\hline
\end{tabular}


2. Компонент Bcmyn може бути розлогим і стислим. Беручи до уваги положення першого етапу алгоритму аналізу термінологічних словників (див. табл.), у вступі подають загальну оцінку первинного тексту, тобто словника. Субкомпонентами вступу є такі: 1) констатація факту появи словника; 2) необхідність, новизна та практична цінність видання; 3 ) аналіз мегаструктурних частин (вступу або передмови, правил користування, переліку скорочень, корпусу словника, списку джерел, покажчика) словника на відповідність принципам їхньої побудови; 4) установлення відповідності типу словника, заявленого в тексті передмови, реальному; 5) з'ясування відповідності призначення словника, зафіксованому в передмові; 6) визначення наукової цінності видання та його відповідності запитам користувачів.

Не менш важливим, хоч і, як показує здійснений аналіз, факультативним, $є$ й субкомпонент автор, коли викладають інформацію про фах укладача, його науковий досвід, належність до певної установи, тобто визначають його авторитет як термінографа.

3. Компонент Основна частина - найбільший за обсягом інформації складник композиції, що є іï ядром. «Якщо у вступі рецензент ніби апріорно оцінює вченого, то в основній частині подає аргументований аналіз публікації, доводить, ілюструє свої положення» (Левчук, 2014: 145). Для створення основної частини рецензії необхідно схарактеризувати переваги й недоліки спеціальної праці, орієнтуючись на положення другого й третього етапів алгоритму аналізу термінологічних словників (див. табл.), тобто зупинитися на аналізі найістотніших елементів макро- й мікроструктури фахового видання.

Наголосімо, що основну частину як найбільший компонент рецензії на термінографічне видання формують такі субкомпоненти: 1) критика макроструктури (реєстру термінів) словника: a) з'ясування відповідності способу побудови реєстру видання; б) аналіз термінологічного складу словника; в) експертизування реєстрових терміноодиниць щодо відповідності вимогам до термінів; 2) аналіз мікроструктури (термінологічної статті) словника: a) характеристика терміностатті за критерієм ефективності репрезентування інформації б) оцінювання мікроструктурних параметрів (заголовного терміна, варіантів, акцентної характеристики, граматичної характеристики, етимологічної довідки, дефініції, системних відношень) словника за критерієм якості їхнього подання. 
Ефективним для викладу в рецензії результатів експертизування структури термінологічного словника, а також його лексикографічних параметрів є, як видається, спосіб, запропонований П. Селігеєм, що стосується розподілення інформації в науковому тексті з урахуванням дихотомії: «старе - нове, відоме - невідоме, головне - другорядне, істотне - неістотне, загальне - конкретне, спеціальне - специфічне, просте - складне, зрозуміле - незрозуміле, звичне незвичне, безперечне - суперечливе» (Селігей, 2015: 60). Крім того, такий підхід дасть змогу «контрастно» схарактеризувати спеціальну працю й аргументовано висновкувати про їі якість.

4. Компонент Висновки є надзвичайно важливим, оскільки передбачає стисле викладення підсумків того, що було висловлено в основній частині. Здебільшого у висновках, попри вказані в основній частині зауваження до параметрів словника, критики ствердно визначають його наукову цінність і підкреслюють важливість та необхідність праці, а також висловлюють поради й побажання стосовно проблемних параметрів термінографічного видання. Узагальнимо інформацію щодо субкомпонентів висновків: 1) остаточний підсумок з'ясування якості словника, установлення його наукової вартості; 2) підведення результатів експертизування складників словника - його мега-, макро- й мікростуктури; 3) висловлення побажань та порад; 4) указівка на призначення словника і його привабливість. У висновковій частині критик, як бачимо, пропонує узагальнений підсумок, загальну оцінку словника.

Отже, композицію рецензії на термінологічний словник розглядаємо як ієрархічну гранд-/ мегаструктуру; складники рецензії Заголовок, Вступ, Основна частина й Висновки є співкомпонентами нижчого рівня ієрархії й створюють їі макроструктуру; субкомпоненти компонентів формують їі мікроструктуру (див. схема).

\section{Висновки}

Особливостями композиції рецензії на термінологічний словник $€$ (1) різнорівневість і полікомпонентність ії системної організації, (2) залежність змісту композиційних компонентів від суті положень алгоритму поетапного оцінювання спеціального видання, (3) аналітичність компонентів рецензії, тобто значна кількість відповідних їм субкомпонентів. Запропонована інваріантна схема-модель композиції 


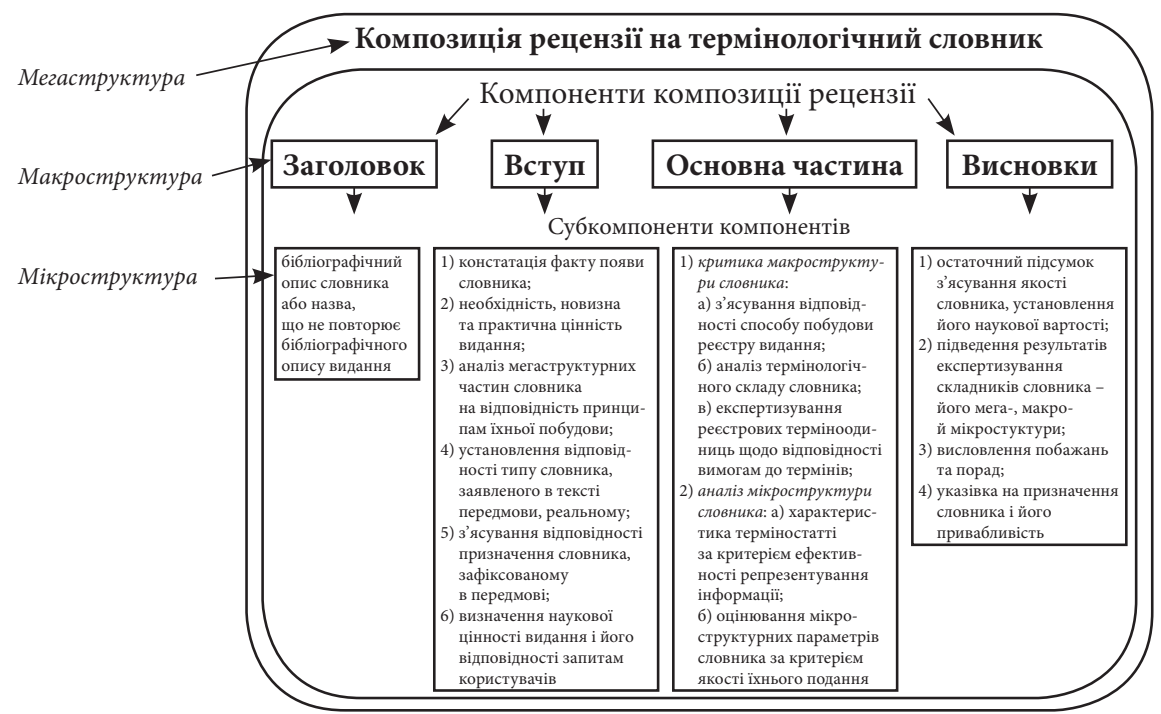

Схема. Інваріантна модель різнорівневої композиції рецензії на термінологічний словник

рецензї на термінологічний словник як різнорівневої системи $є$ «навігатором» у складному процесі рецензування термінографічної праці. Ця схема-модель має методологічне підгрунтя - орієнтування на поетапний алгоритм лексикографічної експертизи спеціальних видань, вона сприятиме розгорнутому, аргументованому й об’єктивному аналізу, уникненню суб’єктивізму й порушенню ознак і меж рецензї як жанрового різновиду критичного субдискурсу. Рецензія, створена з урахуванням запропонованої інваріантної схеми-моделі, може стати стійкою прагматичною жанровою формою, засвідчить якісні зміни в термінографічній критиці та фаховому словникарстві.

\section{ЛІТЕРАТУРА}

1. Беловодская А. Современные медиажанры: рецензия (от теории к практике): учебное пособие. Вильнюс: Vilniaus universitetas, 2016. 106 с. 2. Гуманенко О. О. Місце рецензії в історії наукової періодики. Наукові записки Украйнської академії друкарства. Серія: Соціальні комунікації. Львів 2015. Вип. 1 (50). С. 15-20. 3. Добровольський О. О., Хойнацький М. С. Підготовка оригіналів до видання: на допомогу авторові, рецензентові, редакторові. Київ: Вища шк., 1991. 111 с. 4. Загнітко А. Словник сучасної лінгвістики: поняття і терміни. Донецьк: ДонНУ, 2012. Т. 2. 350 с. 5. Загнітко А. Словник сучасної лінгвістики: поняття і терміни. Донецьк: ДонНУ, 2012. T. 3.426 с. 6. Зинова Е. А. Методика обучения студентов-журналистов рецензии 
как жанру современной медиасферы: дисс. ... к.п.н.: 13.00.02. Москва: МПГУ, 2012. 7. Кайда Л. Г. Композиционная поэтика публицистики: учеб. пособие. Москва: Флинта; Наука, 2006. 144 с. 8. Карнаухова М. В. Русский язык: понимаю, пишу, проверяю. Практический курс. Москва: Изд-во МГГУ «Горная книга», «Эксперт», 2010. 736 с. 9. Краснобаєва-Чорна Ж. Структурні типи оцінного дискурсу (на матеріалі сучасних україномовних рецензій). Лінгвістичні студї. Донецьк: ДонНУ, 2010. Вип. 20. С. 216-222. 10. Космеда Т. Науковий дискурс XXI ст.: нейтралізація типових стильових ознак (на матеріалі української і російської мов). Slavica Wratislaviensia. Wrocław: Wyd-wo Uniwersytetu Wrocławskiego, 2017. № CLXV. S. 217-227. 11. Лассан Э. P. Рецензия как жанр и как речевой акт. Лингвистика речи. Медиастилистика: кол. монография. Москва: Флинта; Наука, 2012. С. 190-206. 12. Левчук I. Комунікативні ознаки рецензійного дискурсу. Studia Ukrainica Posnaniensia. Red. nauk. T. Kosmeda. Poznań: Uniwersytet im. Adama Mickiewicza, 2013. Zesz. I. S. 99-105. https://doi.org/10.14746/ sup.2013.1.12. 13. Левчук I. Особливості структурно-семантичної організації мовознавчих рецензій 30-х років ХХ ст. Вісник Львівського ун-ту. Серія «Філологія». Львів: Львів. нац. ун-т ім. Івана Франка, 2004. Вип. 34, Ч. ІІ. С. 291-297. 14. Левчук І. П. Типологія структурно-семантичної організації рецензій в українській і польській мовах. Науковий вісник ВДУ. Луцьк: Вежа, 2003. № 12. С. 267-272. 15. Михневич А. Е. Ораторское искусство лектора: пособие для школ молодого лектора. Москва: Знание, 1984. 192 с. 16. Молитвина Н. Н. Лингвостилистические особенности современной литературной рецензии. Сибирский филологический журнал. 2016. № 3. С. 230-235. 17. Онуфрієнко Г. Навчальний посібник з алгоритмічними приписами. 2-ге вид. переробл. та доп. Київ: Центр учбової літератури, 2009. 392 с. 18. Петрова Т. (а) Рецензія на термінологічний словник як жанр критичного субдискурсу. Наукові праці Кам'янець-Подільського наи. ун-ту імені Івана Огієнка: Філологічні науки. Кам'янецьПодільський: Аксіома, 2019. Вип. 50. С. 133-139. 19. Петрова Т. О. (б) Теоретикопрактичне значення рецензій на українські термінологічні словники кінця XX ст. - поч. XXI ст. Проблеми загального і слов'янського мовознавства. Дніпро: Ліра, 2019. № 3. C. 96-106. URL: https://doi.org/10.15421/251913. 20. Петрова Т.О. Українська термінографічна критика: від витоків до сучасності. Науковий вісник Наи. ун-ту біоресурсів і природокористування України. Серія: Філологічні науки. Київ: Міленіум, 2018. Вип. 292. С. 208-217. 21. Селігей П. О. Роль композиції у створенні та сприйнятті наукового твору. Мовознавство. 2015. № 2. С. 54-63. 22. Тимошик М. Книга для автора, редактора, видавця: практ. посіб. 2-ге вид., стереотипне. Київ: Наша культура і наука, 2006. 560 с. 23. Тищенко О. Композиційна структура грецьких газетних літературних рецензій. Південний архів. Філологічні науки. Херсон: Херсон. держ. унт, 2017. Вип. 67. С. 149-151. 24. Хомутова Т. Н., Кравцова Е. В. Научная рецензия: интегральный подход. Язык и культура. Томск, 2014. № 1 (25). С. 70-76. 25. Яворська С. М. Рецензія як тип тексту (на матеріалі англомовної рецензії): автореф. дис. ... канд. філол. наук: 10.02.04. Львів, 2000. 24 с. 26. Яценко Н. Жанрово-стильова специфіка наукової рецензії. Украӥнська мова. Київ: ІУМ НАН України, 2017. № 1. С. 92-101. 27. Литературный энциклопедический словарь / под общ. ред. В. М. Кожевникова, П. А. Николаева. Москва: Советская энциклопедия, 1987. С. 752. 


\section{REFERENCES}

1. Belovodskaya, A. (2016). Sovremennye mediazhanry: recenziya (ot teorii k praktike): uchebnoe posobie [Modern media genres: review (from theory to practice): tutorial]. Vil'nyus: Vilniaus universitetas [in Lithuania]. 2. Humanenko, O. O. (2015). Mistse retsenzii v istorii naukovoi periodyky [Place of review in history of scientific periodicals]. Naukovi zapysky Ukrainskoi akademii drukarstva. Seriia: Sotsialni komunikatsii-Scientific notes of the Ukrainian Academy of Printing. Series: Social Communications, 1 (50). 15-20 [in Ukrainian]. 3. Dobrovolskyi, O. O. \& Khoinatskyi, M. S. (1991). Pidhotovka oryhinaliv do vydannia: na dopomohu avtorovi, retsenzentovi, redaktorovi [Preparation of originals for publication: to assist author, reviewer, editor]. Kyiv: Vyshcha shk. [in Ukrainian]. 4. Zahnitko, A. (2012). Slovnyk suchasnoi linhvistyky: poniattia i terminy [Modern Linguistics Dictionary: concepts and terms]. (Vol. 2). Donetsk: DonNU [in Ukrainian]. 5. Zahnitko, A. (2012). Slovnyk suchasnoi linhvistyky: poniattia i terminy [Modern Linguistics Dictionary: concepts and terms]. (Vol. 3). Donetsk: DonNU [in Ukrainian]. 6. Zinova, E. A. (2012). Metodika obucheniya studentov-zhurnalistov recenzii kak zhanru sovremennoj mediasfery [Methods of teaching students-journalists a review as genre of modern media sphere]. Candidate's thesis. Moskva: MPGU [in Russian]. 7. Kajda, L. G. (2006). Kompozicionnaya poe'tika publicistiki: ucheb. posobie. [Compositional poetics of publicism: tutorial]. Moskva: Flinta; Nauka [in Russian]. 8. Karnauxova, M. V. (2010). Russkij yazyk: ponimayu, pishu, proveryayu. Prakticheskij kurs [Russian language: I understand, write and check. Practical course]. Moskva: Izdvo MGGU «Gornaya kniga», «E'kspert» [in Russian]. 9. Krasnobaieva-Chorna, Zh. (2010). Strukturni typy otsinnoho dyskursu (na materiali suchasnykh ukrainomovnykh retsenzii). [Structural types of evaluative discourse (based on contemporary Ukrainianlanguage reviews)]. Linhvistychni studii - Linguistic Studios, 20, 216-222 [in Ukrainian]. 10. Kosmeda, T. (2017). Naukovyi dyskurs XX st.: neitralizatsiia typovykh stylovykh oznak (na materiali ukrainskoi i rosiiskoi mov). [Scientific discourse of the 21st century: neutralization of typical stylistic features (on material of Ukrainian and Russian languages)]. Slavica Wratislaviensia, CLXV, 217-227 [in Polish]. 11. Lassan, E. R. (2012). Recenziya kak zhanr i kak rechevoj akt. Lingvistika rechi. Mediastilistika: kol. monografiya [Review as genre and speech act. Speech linguistics. Mediastylistics: coll. monography]. Moskva: Flinta; Nauka [in Russian]. 12. Levchuk, I. (2013). Komunikatyvni oznaky retsenziinoho dyskursu [Communicative features of review discourse]. Studia Ukrainica Posnaniensia, I, 99-1 [in Polish]. 13. Levchuk, I. (2004). Osoblyvosti strukturno-semantychnoi orhanizatsii movoznavchykh retsenzii 30-kh rokiv XX st. [Features of structural-semantic organization of linguistic reviews of the 1930 s.]. Visnyk Lvivskoho un-tu. Seriia «Filolohiia»-Bulletin of the University of Lviv. Philology Series, 34 (II), 291-297 [in Ukrainian]. 14. Levchuk, I. P. (2003). Typolohiia strukturno-semantychnoi orhanizatsii retsenzii v ukrainskii i polskii movakh [Typology of structural-semantic organization of reviews in Ukrainian and Polish languages]. Naukovyi visnyk VDU - Scientific Bulletin of Volyn State University, 12, 267-272 [in Ukrainian]. 15. Mixnevich, A. E. (1984). Oratorskoe iskusstvo lektora: posobie dlya shkol molodogo lektora [Speaking art of lecturer: textbook for young lecturer's schools]. Moskva: Znanie [in Russian]. 16. Molitvina, N. N. (2016). Lingvostilisticheskie osobennosti sovremennoj literaturnoj recenzii [Linguostylistic features of contemporary literary review]. Sibirskij filologicheskij zhurnal - Siberian Philological Journal, 3, 230235 [in Russian]. 17. Onufriienko, H. (2009). Navchalnyi posibnyk $z$ algorytmichnymy 
prypysamy [Tutorial with algorithmic instructions] (2nd ed., rev.). Kyiv: Tsentr uchbovoi literatury [in Ukrainian]. 18. Petrova, T. (2019a) Retsenziia na terminolohichnyi slovnyk yak zhanr krytychnoho subdyskursu [Terminology dictionary review as genre of critical subdiscourse]. Naukovi pratsi Kamianets-Podilskoho nats. un-tu imeni Ivana Ohiienka: Filolohichni nauky - Scientific works of Kamyanets-Podilskyi nat. Ivan Ogiyenko University: Philological Sciences, 50, 133-139 [in Ukrainian]. 19. Petrova, T. O. (2019b). Teoretykopraktychne znachennia retsenzii na ukrainski terminolohichni slovnyky kintsia XX st. poch. XXI st. [Theoretical and practical significance of reviews of Ukrainian terminology dictionaries of the late 20th century - beginning of the 21st century]. Problemy zahalnoho i slovianskoho movoznavstva - Problems of General and Slavic Linguistics, 3, 96-106 [in Ukrainian]. 20. Petrova, T. O. (2018). Ukrainska terminohrafichna krytyka: vid vytokiv do suchasnosti [Ukrainian terminographic criticism: from origins to the present]. Naukovyi visnyk Nats. un-tu bioresursiv i pryrodokorystuvannia Ukrainy. Seriia: Filolohichni nauky Scientific Bulletin Nat. of bio-resources and nature management of Ukraine. Series: Philological Sciences, 292, 208-217 [in Ukrainian]. 21. Selihei, P. O. (2015). Rol kompozytsii u stvorenni ta spryiniatti naukovoho tvoru [Role of composition in creation and perception of scientific work ]. Movoznavstvo - Linguistics, 2, 54-63 [in Ukrainian]. 22. Tymoshyk, M. (2006). Knyha dlia avtora, redaktora, vydavtsia: prakt. posib. [Book for author, editor and publisher: tutorial] (2nd ed., rev.). Kyiv: Nasha kultura i nauka [in Ukrainian]. 23. Tyshchenko, O. (2017). Kompozytsiina struktura hretskykh hazetnykh literaturnykh retsenzii [Composite structure of Greek newspaper literary reviews]. Pivdennyi arkhiv. Filolohichni nauky Southern Archive. Philological Sciences, 67, 149-151 [in Ukrainian]. 24. Xomutova, T. N., Kravcova, E. V. (2014). Nauchnaya recenziya: integral'nyj podxod [Scientific review: integral approach]. Yazyk i kul'tura - Language and culture, 1 (25), $70-76$ [in Russian]. 25. Yavorska, S. M. (2000). Retsenziia yak typ tekstu (na materiali anhlomovnoi retsenzii) [Review as text type (based on English-language review material)]. Extended abstract of candidate's thesis. Lviv: Lviv. nats. un-t im. I. Franka [in Ukrainian]. 26. Yatsenko, N. (2017). Zhanrovostylova spetsyfika naukovoi retsenzii [Genre and style specificity of scientific review ]. Ukrainska mova - Ukrainian language, 1, 92-101 [in Ukrainian]. 27. Kozhevnikova, V. M., Nikolaeva, P. A. (Ed.). (1987). Literaturnyj e’nciklopedicheskij slovar' [Literary Encyclopedic Dictionary]. Moskva: Sovetskaya e'nciklopediya [in Russian].

Петрова Тетяна Олексіӥвна - кандидат філологічних наук, доцент кафедри мовних дисциплін, Харківський національний аграрний університет імені В. В. Докучаєва; Харківська область, Харківський район, п/в “Докучаєвське - 2”, 62483, Україна.

Tel.: +38-095-574-76-41

E-mail: t-petrova@ukr.net

http://orcid.org/0000-0002-9534-9891

Petrova Tetiana - PhD in Philology, Associate Professor, Department of Linguistic Disciplines, Kharkiv National Agrarian University named after V. V. Dokuchaiev; Kharkiv region, Kharkiv district, p/o «Dokuchaievske- 2», 62483, Ukraine. 